\title{
Synthesis and characterization of mixed ligand complexes of bio-metals with pyrimidine nucleoside (uridine) and amino acids
}

\author{
P RABINDRA REDDY* and A MOHAN REDDY \\ Department of Chemistry, Osmania University, Hyderabad 500 007, India
}

MS received 24 December 1999; revised 28 August 2000

\begin{abstract}
The mixed ligand complexes of $\mathrm{Cu}(\mathrm{II}), \mathrm{Ni}(\mathrm{II})$ and $\mathrm{Co}(\mathrm{II})$ with uridine and amino acids, L-alanine, L-phenylalanine and L-tryptophan were synthesized and characterized by elemental analysis, conductivity data, infrared spectra, electronic spectra and magnetic susceptibility data. In these complexes, the nucleoside (uridine) acts as a monodentate ligand coordinating through $\mathrm{O}(4)$ under the conditions of investigation, whereas the amino acids coordinate through the carboxylate oxygen and the amino nitrogen. Distorted octahedral geometry for $\mathrm{Cu}(\mathrm{II})$ and octahedral geometries for both $\mathrm{Ni}(\mathrm{II})$ and $\mathrm{Co}(\mathrm{II})$ are proposed.
\end{abstract}

Keywords. Mixed ligand complexes; divalent complexes of $\mathrm{Cu}, \mathrm{Ni}$ and $\mathrm{Co}$; uridine; L-aminoacids.

\section{Introduction}

Metal ion-mediated reactions involving nucleic acid constituents and aminoacid side chains have been the subject of several investigations ${ }^{1-6}$. These reactions provide an opportunity to identify the nature of such interactions in vivo as they serve as models for many metalloenzyme reactions. Among the nucleosides (purines and pyrimidines), pyrimidines are considered simple as far as their interaction with metal ions are concerned, since they possess fewer coordination sites compared to purines. However, even pyrimidine nucleosides are found to exhibit complex behaviour ${ }^{7}$. Uridine is unique since its coordinating tendencies are highly $p \mathrm{H}$ dependent. It contains three potential metal ion binding sites viz.: $\mathrm{O}(2), \mathrm{N}(3)$ and $\mathrm{O}(4)$. The dissociation of a proton from $\mathrm{N}(3)$ occurs only at a high $p \mathrm{H}(\sim 9 \cdot 0)$ leaving the other two as viable alternate sites for metal ion binding at biological $p \mathrm{H}$. Among these two, $\mathrm{O}(4)$ is preferred as it possesses high electron density ${ }^{8,9}$ compared to $\mathrm{O}(2)$. In order to gather more information, we thought it was important to investigate the interaction of uridine and amino acids with the biologically important metal ions, $\mathrm{Cu}(\mathrm{II}), \mathrm{Ni}(\mathrm{II})$ and $\mathrm{Co}(\mathrm{II})$. The mixed ligand complexes of $\mathrm{Zn}$ (II) with pyrimidine nucleosides and amino acids were reported recently ${ }^{10,11}$. The complexes were characterized based on elemental analysis, conductivity data, infrared spectra, electronic spectra and magnetic susceptibility data and their bonding modes assigned. Uridine acts as a monodentate ligand with exclusive $\mathrm{O}(4)$ binding under the conditions employed whereas the amino acids act as bidentate ligands coordinating through the carboxylate oxygen and the amino nitrogen. Distorted octahedral geometry for $\mathrm{Cu}(\mathrm{II})$ and octahedral geometries for both $\mathrm{Ni}(\mathrm{II})$ and $\mathrm{Co}(\mathrm{II})$ are proposed.

*For correspondence 


\section{Experimental}

\subsection{Materials}

The ligands uridine (urd), L-alanine (L-Ala), L-phenylalanine (L-Phe) and L-tryptophan (L-Trp), were obtained from Sigma Chemical Company (USA). All the metal ions $\mathrm{Cu}(\mathrm{II})$, $\mathrm{Ni}(\mathrm{II})$ and $\mathrm{Co}(\mathrm{II})$ were of Analar grade (BDH). They were used in the form of chlorides without further purification.

\subsection{Physical measurements and analysis}

2.2a Infrared spectra and conductivity data: IR spectra were recorded (as $\mathrm{kBr}$ discs) on infrared spectrophotometers; IR-435 Shimadzu in the $4000-400 \mathrm{~cm}^{-1}$ region, and a Perkin-Elmer for FTIR. Far infrared spectra in the region $800-200 \mathrm{~cm}^{-1}$ were recorded on a Perkin-Elmer 1430. Conductivity measurements were performed using a Digisun Digital conductivity bridge (model: DI-909) and a dip-type cell calibrated with $\mathrm{KCl}$ solution.

2.2b Electronic spectra and magnetic susceptibility data: The electronic spectra of the complexes were recorded in $\mathrm{DMSO} / \mathrm{H}_{2} \mathrm{O}$ on a Shimadzu UV-160A spectrophotometer. The magnetic susceptibilities of the complexes were recorded on a Faraday balance (Cahn-7550-03) at room temperature using $\mathrm{Hg}\left[\mathrm{Co}(\mathrm{CNS})_{4}\right]$ as the standard.

2.2c Elemental analysis: Carbon, hydrogen and nitrogen analyses were obtained on a microanalytical Perkin-Elmer 240C elemental analyser while metal analysis was carried out on an atomic absorption spectrometer, Perkin-Elmer 2380. The presence of chlorides is established by decomposing the complexes and titrating the liberated chlorides with $\mathrm{AgNO}_{3}$.

\subsection{Synthesis of metal complexes}

2.3a Copper complexes: (i) Equimolar $(1.17 \mathrm{mmols})$ aqueous solutions of L-alanine (L-Ala) and uridine (urd) were added simultaneously to another aqueous solution containing $1.17 \mathrm{mmol}$ of copper chloride. (ii) Similarly, equimolar (1.17 mmols) aqueous solutions of L-phenylalanine (L-Phe) and uridine (urd) were added simultaneously to another aqueous solution containing $1.17 \mathrm{mmol}$ of copper chloride. (iii) Finally, equimolar (0.58 mmols) aqueous solutions of L-tryptophan (L-Trp) and uridine (urd) were added simultaneously to another aqueous solution containing $0.58 \mathrm{mmol}$ of copper chloride. The above mixtures were refluxed on a heating mantle $(\sim 18 \mathrm{~h})$ during which the colour of the solutions changed from blue to green (precipitate not obtained). These green coloured solutions were further refluxed for another 10-12 h, after which light brown coloured compounds were obtained and a precipitate started appearing. When no further precipitation was observed after a few hours, the refluxing was stopped and the precipitate was filtered and washed with water (to remove unreacted materials and impurities). The $p \mathrm{H}$ of the solutions was between 2 and 3. Purities of these compounds were established by TLC in a mixture of solvents, methanol and ethylacetate, in a 1:4 ratio. 
$2.3 b$ Nickel complexes: (i) An aqueous solution containing $0.84 \mathrm{mmol}$ of L-alanine (L-Ala) and $0.84 \mathrm{mmol}$ of uridine (urd) were added simultaneously to another aqueous solution containing $0.84 \mathrm{mmol}$ of nickel chloride. (ii) Similarly, aqueous solutions containing $0.84 \mathrm{mmol}$ of L-phenylalanine (L-Phe) and $0.84 \mathrm{mmol}$ of uridine (urd) were added simultaneously to another aqueous solution containing $0.84 \mathrm{mmol}$ of nickel chloride. (iii) Finally, an aqueous solution containing $0.63 \mathrm{mmol}$ of L-tryptophan (L-Trp) and $0.63 \mathrm{mmol}$ of uridine (urd) were added simultaneously to another aqueous solution containing $0.63 \mathrm{mmol}$ of nickel chloride. These mixtures were refluxed on a heating mantle during which the colour of the solutions changed from green to yellow $(\sim 22 \mathrm{~h})$ (precipitate not obtained). These yellow coloured solutions were further refluxed for another $20 \mathrm{~h}$, when light brown coloured compounds were obtained, which were filtered and washed with water. The $p \mathrm{H}$ of these solutions was 4 . The purities of these compounds were determined by TLC in a mixture of solvents, methanol and ethylacetate, in a $1: 4$ ratio.

2.3c Cobalt complexes: (i) Equimolar $(1.27 \mathrm{mmols})$ aqueous solutions of L-alanine (L-Ala) and uridine (urd) were added simultaneously to another aqueous solution, containing $1.31 \mathrm{mmol}$ of cobalt chloride. (ii) Similarly, equimolar $(0.81 \mathrm{mmols})$ aqueous solutions of L-phenylalanine (L-Phe) and uridine (urd) were added simultaneously to another aqueous solution containing $0.81 \mathrm{mmol}$ of cobalt chloride. (iii) Finally, equimolar (1.69 mmols) aqueous solutions of L-tryptophan (L-Trp) and uridine (urd) were added simultaneously to another aqueous solution containing $1.69 \mathrm{mmol}$ of cobalt chloride. The above mixtures were refluxed on a heating mantle during which the colour of the solutions changed from pink to yellow $(\sim 30 \mathrm{~h})$ (precipitate not obtained). These yellow coloured solutions were further refluxed for another 10-12 h, when the colour of the solutions changed from yellow to green (precipitate not obtained). These were filtered and washed with water (to remove unreacted materials and impurities), and then were concentrated to half their original volumes. Beautiful dark green coloured compounds were obtained on keeping these for two months. The $p \mathrm{H}$ of the solutions was between 5 and 6 . The purities of these complexes were established by TLC in a mixture of solvents, methanol and ethylacetate, in a 1:4 ratio.

\section{Results and discussion}

Analytical and conductivity data of the complexes are presented in table 1 . The analytical data correspond to a metal-uridine-aminoacid ratio of 1:1:1 and two moles of water per mole of metal for complexes 1, 3 and 9 and three moles of water for complexes 2, 4, 5, 6, 7 and 8 . The conductivity values in $\mathrm{DMSO} / \mathrm{H}_{2} \mathrm{O}$ correspond to $1: 1$ electrolytes for complexes 2, 4, 5, 6, 7 and 8, while complexes 1,3 and 9 are non-electrolytes ${ }^{12}$.

The infrared spectra of various mixed ligand complexes synthesized are compiled in table 2. The infrared spectra of these complexes in comparison with free uridine and the respective free amino acids show characteristic band positions, shifts and intensities, which can be correlated to monodentate uridine binding and bidentate amino acid chelation. Besides, metal binding through water molecules and chloride is also evident from the IR spectra ${ }^{13-17}$. Characteristic IR bands of free uridine corresponding to $v \mathrm{C}_{2}=\mathrm{O}$ and $\mathrm{v}(\mathrm{N}-\mathrm{H}, \mathrm{C}-\mathrm{N})$ are shown in the spectra of the complexes without any negative shifts, thus ruling out their participation in metal coordination. Nominal upward shifts in these vibrational frequencies are presumed to be the consequence of involvement of uridine in 
coordination through a different coordination site, probably the $\mathrm{C}_{4}=\mathrm{O}$ site. Considerable shifts in $v C_{4}=\mathrm{O}\left(\Delta v C_{4}=\mathrm{O} \sim 36-86 \mathrm{~cm}^{-1}\right)$ stretching frequencies, which correspond to the $\mathrm{C}_{4}=\mathrm{O}$ of uridine of all the metal complexes, clearly indicate the involvement of $\mathrm{C}_{4}=\mathrm{O}$ of uridine in metal coordination ${ }^{18-22,26}$.

As regards chelation through aminoacids, the IR spectra exhibit significant features in the $\mathrm{vNH}_{2}$ and $v \mathrm{COO}^{-}$regions. It is worthwhile to mention here that free aminoacids exist as zwitterions $\left(\mathrm{N}_{3}^{+} \mathrm{H}_{3} \mathrm{AA} . \mathrm{COO}^{-}\right)$and the IR spectra of these cannot be compared entirely with those of metal complexes as aminoacids in metal complexes do not exist as zwitterions. Free aminoacids with $\mathrm{N}_{3}^{+} \mathrm{H}_{3}$ functions in particular show $\mathrm{vN}^{\dagger} \mathrm{H}_{3}$ in the range of 3130-3030 $\mathrm{cm}^{-1}$. In the complexes, $\mathrm{N}_{3}^{+} \mathrm{H}_{3}$ gets deprotonated and binds to metal through the neutral $\mathrm{NH}_{2}$ group. The transformation of ${ }^{+} \mathrm{H}_{3}$ to $\mathrm{NH}_{2}$ must result in an upward shift in $\mathrm{vNH}_{2}$ and free aminoacids. At the isoelectric point, they must show $\mathrm{vNH}_{2}$ in the region $3500-3300 \mathrm{~cm}^{-1} 23-25$. In the present complexes, the IR spectra show characteristic bands in the region 3246-3150 $\mathrm{cm}^{-1}$, which are lower compared to those of free $\mathrm{vNH}_{2}$. Hence, it can be concluded that the nitrogen of the amino group is involved in coordination. The IR spectra show strong evidence in support of the involvement of carboxylate group in coordination. In comparison with free aminoacids, the $\mathrm{vCOO}^{-}$(asym) shows positive shifts and $\mathrm{vCOO}^{-}$(sym) records negative shifts, which confirm the monodenticity ${ }^{13,17}$ of the carboxylate group.

Table 1. Analytical and conductivity data of mixed ligand complexes of $\mathrm{Cu}(\mathrm{II})$, $\mathrm{Ni}(\mathrm{II})$ and $\mathrm{Co}(\mathrm{II})$ with pyrimidine nucleoside (uridine) and aminoacids.

\begin{tabular}{|c|c|c|c|c|c|}
\hline \multirow[b]{2}{*}{ Complex } & \multicolumn{4}{|c|}{ Found (Calcd.) \% } & \multirow{2}{*}{$\begin{array}{c}\stackrel{\wedge}{\wedge} \\
\left(\mathrm{ohm}^{-1} \mathrm{~cm}^{-1} \mathrm{~mol}^{-1}\right) \\
(\text { in DMSO })\end{array}$} \\
\hline & Carbon & Hydrogen & Nitrogen & Metal & \\
\hline $\begin{array}{l}{\left[\mathrm{Cu}(\text { urd })(\mathrm{L}-\mathrm{Ala})\left(\mathrm{H}_{2} \mathrm{O}\right)_{2} \mathrm{Cl}\right], \mathbf{1}} \\
{\left[\mathrm{CuC}_{12} \mathrm{H}_{22} \mathrm{~N}_{3} \mathrm{O}_{10} \mathrm{Cl}\right]}\end{array}$ & $\begin{array}{l}31 \cdot 06 \\
(30 \cdot 75)\end{array}$ & $\begin{array}{c}4 \cdot 22 \\
(4 \cdot 69)\end{array}$ & $\begin{array}{c}9.28 \\
(8 \cdot 97)\end{array}$ & $\begin{array}{c}13 \cdot 11 \\
(13 \cdot 57)\end{array}$ & 015 \\
\hline $\begin{array}{l}{\left[\mathrm{Cu}(\text { urd })(\mathrm{L}-\mathrm{Phe})\left(\mathrm{H}_{2} \mathrm{O}\right)_{3}\right] \mathrm{Cl}, 2} \\
{\left[\mathrm{CuC}_{18} \mathrm{H}_{28} \mathrm{~N}_{3} \mathrm{O}_{11}\right] \mathrm{Cl}}\end{array}$ & $\begin{array}{c}38.01 \\
(38 \cdot 41)\end{array}$ & $\begin{array}{c}5 \cdot 21 \\
(4 \cdot 98)\end{array}$ & $\begin{array}{c}7 \cdot 74 \\
(7 \cdot 47)\end{array}$ & $\begin{array}{c}11.02 \\
(11.29)\end{array}$ & 081 \\
\hline $\begin{array}{l}{\left[\mathrm{Cu}(\text { urd })(\mathrm{L}-\mathrm{Trp})\left(\mathrm{H}_{2} \mathrm{O}\right)_{2} \mathrm{Cl}\right], \mathbf{3}} \\
{\left[\mathrm{CuC}_{20} \mathrm{H}_{27} \mathrm{~N}_{4} \mathrm{O}_{10} \mathrm{Cl}\right]}\end{array}$ & $\begin{array}{c}41 \cdot 81 \\
(41 \cdot 14)\end{array}$ & $\begin{array}{c}4 \cdot 34 \\
(4 \cdot 63)\end{array}$ & $\begin{array}{l}9.98 \\
(9.59)\end{array}$ & $\begin{array}{c}10 \cdot 39 \\
(10 \cdot 89)\end{array}$ & 007 \\
\hline $\begin{array}{l}{\left[\mathrm{Ni}(\text { urd })(\mathrm{L}-\mathrm{Ala})\left(\mathrm{H}_{2} \mathrm{O}\right)_{3}\right] \mathrm{Cl}, \mathbf{4}} \\
{\left[\mathrm{NiC}_{12} \mathrm{H}_{24} \mathrm{~N}_{3} \mathrm{O}_{11}\right] \mathrm{Cl}}\end{array}$ & $\begin{array}{c}29 \cdot 12 \\
(29 \cdot 91)\end{array}$ & $\begin{array}{c}4 \cdot 46 \\
(4 \cdot 98)\end{array}$ & $\begin{array}{c}8 \cdot 12 \\
(8 \cdot 72)\end{array}$ & $\begin{array}{c}12 \cdot 58 \\
(12 \cdot 19)\end{array}$ & 095 \\
\hline $\begin{array}{l}{\left[\mathrm{Ni}(\text { urd })(\mathrm{L}-\mathrm{Phe})\left(\mathrm{H}_{2} \mathrm{O}\right)_{3}\right] \mathrm{Cl}, \mathbf{5}} \\
{\left[\mathrm{NiC}_{18} \mathrm{H}_{28} \mathrm{~N}_{3} \mathrm{O}_{11}\right] \mathrm{Cl}}\end{array}$ & $\begin{array}{c}39 \cdot 23 \\
(38 \cdot 74)\end{array}$ & $\begin{array}{c}5 \cdot 19 \\
(5 \cdot 02)\end{array}$ & $\begin{array}{c}7 \cdot 21 \\
(7 \cdot 53)\end{array}$ & $\begin{array}{c}10 \cdot 02 \\
(10 \cdot 53)\end{array}$ & 081 \\
\hline $\begin{array}{l}{\left[\mathrm{Ni}(\text { urd })(\mathrm{L}-\mathrm{Trp})\left(\mathrm{H}_{2} \mathrm{O}\right)_{3}\right] \mathrm{Cl}, \mathbf{6}} \\
{\left[\mathrm{NiC}_{20} \mathrm{H}_{29} \mathrm{~N}_{4} \mathrm{O}_{11}\right] \mathrm{Cl}}\end{array}$ & $\begin{array}{c}40 \cdot 02 \\
(40 \cdot 23)\end{array}$ & $\begin{array}{c}4 \cdot 36 \\
(4 \cdot 86)\end{array}$ & $\begin{array}{l}9 \cdot 11 \\
(9 \cdot 39)\end{array}$ & $\begin{array}{l}9 \cdot 34 \\
(9 \cdot 84)\end{array}$ & 041 \\
\hline $\begin{array}{l}{\left[\mathrm{Co}(\text { urd })(\mathrm{L}-\mathrm{Ala})\left(\mathrm{H}_{2} \mathrm{O}\right)_{3}\right] \mathrm{Cl}, 7} \\
{\left[\mathrm{CoC}_{12} \mathrm{H}_{24} \mathrm{~N}_{3} \mathrm{O}_{11}\right] \mathrm{Cl}}\end{array}$ & $\begin{array}{c}30 \cdot 11 \\
(29 \cdot 89)\end{array}$ & $\begin{array}{c}4 \cdot 44 \\
(4 \cdot 98)\end{array}$ & $\begin{array}{c}9.32 \\
(8.72)\end{array}$ & $\begin{array}{c}12 \cdot 94 \\
(12 \cdot 24)\end{array}$ & 104 \\
\hline $\begin{array}{l}{\left[\mathrm{Co}(\text { urd })(\mathrm{L}-\mathrm{Phe})\left(\mathrm{H}_{2} \mathrm{O}\right)_{3}\right] \mathrm{Cl}, 8} \\
{\left[\mathrm{CoC}_{18} \mathrm{H}_{28} \mathrm{~N}_{3} \mathrm{O}_{11}\right] \mathrm{Cl}}\end{array}$ & $\begin{array}{c}39.41 \\
(38 \cdot 72)\end{array}$ & $\begin{array}{c}5 \cdot 09 \\
(5 \cdot 02)\end{array}$ & $\begin{array}{c}7 \cdot 01 \\
(7 \cdot 53)\end{array}$ & $\begin{array}{c}10 \cdot 12 \\
(10 \cdot 57)\end{array}$ & 127 \\
\hline $\begin{array}{l}{\left[\mathrm{Co}(\text { urd })(\mathrm{L}-\mathrm{Trp})\left(\mathrm{H}_{2} \mathrm{O}\right)_{2} \mathrm{Cl}\right], \mathbf{9}} \\
{\left[\mathrm{CoC}_{20} \mathrm{H}_{27} \mathrm{~N}_{4} \mathrm{O}_{10} \mathrm{Cl}\right]}\end{array}$ & $\begin{array}{c}42 \cdot 14 \\
(41 \cdot 46)\end{array}$ & $\begin{array}{c}4 \cdot 37 \\
(4 \cdot 66)\end{array}$ & $\begin{array}{l}9 \cdot 16 \\
(9 \cdot 67)\end{array}$ & $\begin{array}{c}10 \cdot 72 \\
(10 \cdot 18)\end{array}$ & 032 \\
\hline
\end{tabular}




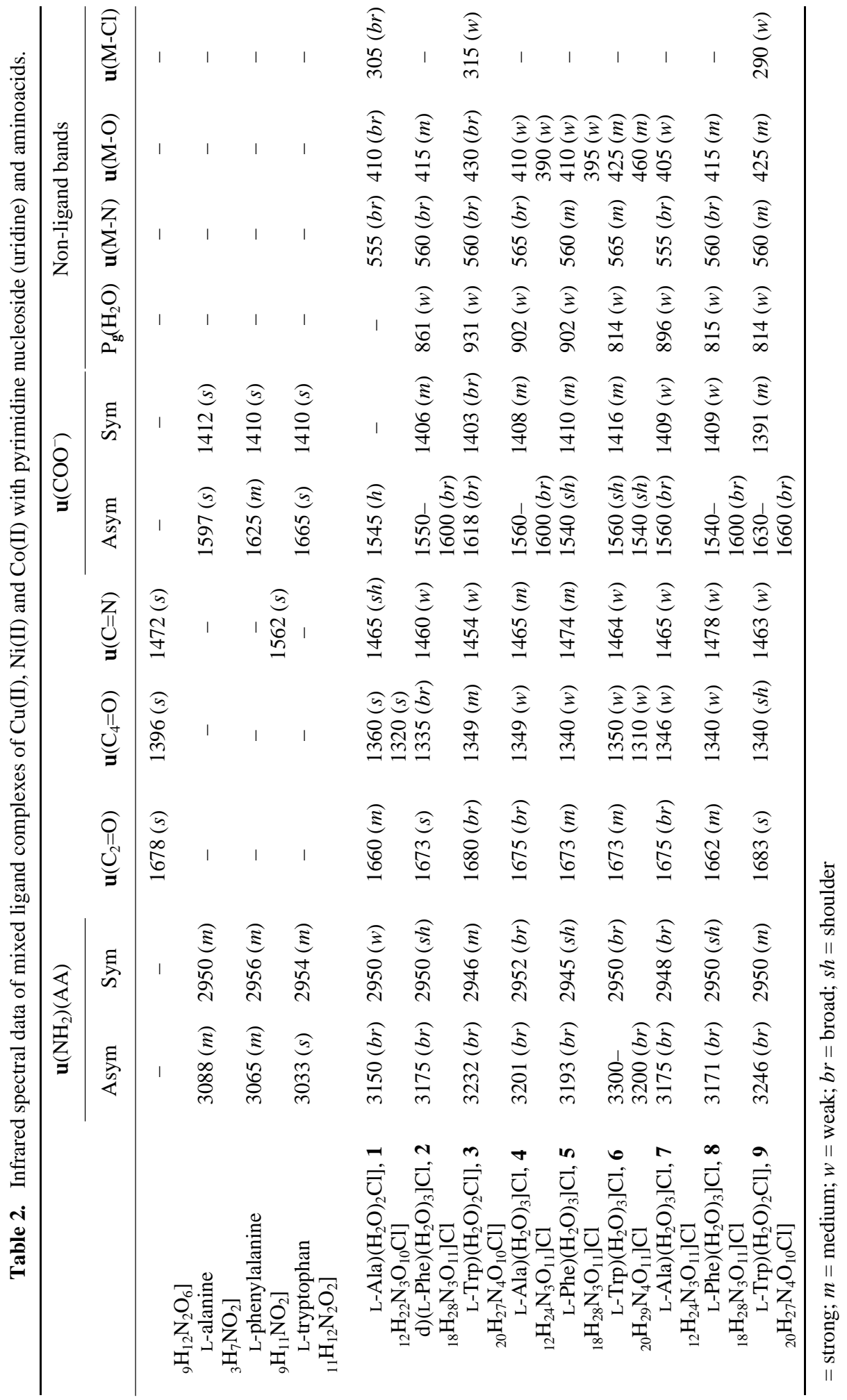


(a)

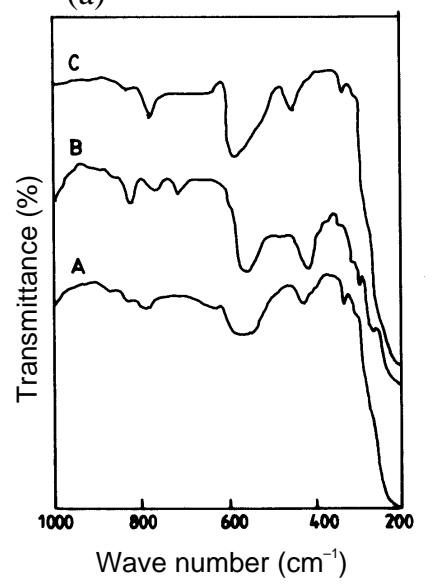

(b)

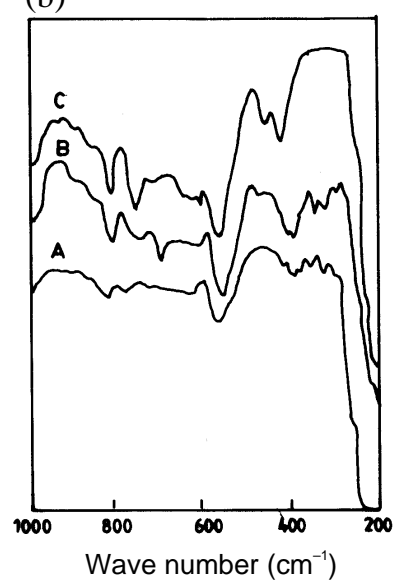

(c)

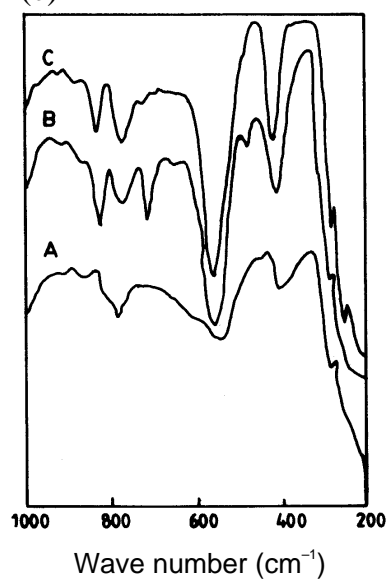

Figure 1. Far infrared spectra of (a) $\left[\mathrm{Cu}(\mathrm{urd})(\mathrm{L}-\mathrm{Ala})\left(\mathrm{H}_{2} \mathrm{O}\right)_{2} \mathrm{Cl}\right](\mathrm{A}),[\mathrm{Cu}(\mathrm{urd})(\mathrm{L}-$ $\left.\mathrm{Phe})\left(\mathrm{H}_{2} \mathrm{O}\right)_{3}\right] \mathrm{Cl}(\mathrm{B}),\left[\mathrm{Cu}(\right.$ urd $\left.)(\mathrm{L}-\mathrm{Trp})\left(\mathrm{H}_{2} \mathrm{O}\right)_{2} \mathrm{Cl}\right](\mathrm{C})$; (b) [Ni(urd)(L-Ala) $\left.\left(\mathrm{H}_{2} \mathrm{O}\right)_{3}\right] \mathrm{Cl}(\mathrm{A})$, $\left[\mathrm{Ni}(\right.$ urd $\left.)(\mathrm{L}-\mathrm{Phe})\left(\mathrm{H}_{2} \mathrm{O}\right)_{3}\right] \mathrm{Cl} \quad$ (B), $\left[\mathrm{Ni}(\right.$ urd $\left.)(\mathrm{L}-\mathrm{Trp})\left(\mathrm{H}_{2} \mathrm{O}\right)_{3}\right] \mathrm{Cl} \quad(\mathrm{C}) ; \quad($ c) $\quad[\mathrm{Co}(\mathrm{urd})(\mathrm{L}-$ Ala) $\left.\left(\mathrm{H}_{2} \mathrm{O}\right)_{3}\right] \mathrm{Cl}(\mathrm{A})$, [Co(urd)(L-Phe) $\left.\left(\mathrm{H}_{2} \mathrm{O}\right)_{3}\right] \mathrm{Cl}(\mathrm{B}),\left[\mathrm{Co}(\mathrm{urd})(\mathrm{L}-\mathrm{Trp})\left(\mathrm{H}_{2} \mathrm{O}\right)_{2} \mathrm{Cl}\right](\mathrm{C})$.

Table 3. Electronic spectra and magnetic data of mixed ligand complexes of $\mathrm{Cu}(\mathrm{II})$, $\mathrm{Ni}(\mathrm{II})$ and $\mathrm{Co}(\mathrm{II})$ with pyrimidine nucleoside (uridine) and aminoacids.

\begin{tabular}{|c|c|c|}
\hline Complex & $\begin{array}{l}\mu_{\text {eff }}(\mathrm{BM}) \\
\text { (temp. K) }\end{array}$ & $\begin{array}{l}\text { Electronic spectral bands } v_{\max }\left(\mathrm{cm}^{-1}\right) \\
\quad\left(\text { in } \mathrm{DMSO} / \mathrm{H}_{2} \mathrm{O}\right)\end{array}$ \\
\hline $\begin{array}{l}{\left[\mathrm{Cu}(\text { urd })(\mathrm{L}-\mathrm{Ala})\left(\mathrm{H}_{2} \mathrm{O}\right)_{2} \mathrm{Cl}\right], \mathbf{1}} \\
{\left[\mathrm{CuC}_{12} \mathrm{H}_{22} \mathrm{~N}_{3} \mathrm{O}_{10} \mathrm{Cl}\right]}\end{array}$ & $\begin{array}{l}2 \cdot 01 \\
(301)\end{array}$ & $\begin{array}{l}13,020(768 \cdot 0 \mathrm{~nm}) ; 22,421(446 \cdot 0 \mathrm{~nm}) ; \\
38,314(261 \cdot 0 \mathrm{~nm})\end{array}$ \\
\hline $\begin{array}{l}{\left[\mathrm{Cu}(\text { urd })(\mathrm{L}-\mathrm{Phe})\left(\mathrm{H}_{2} \mathrm{O}\right)_{3}\right] \mathrm{Cl}, 2} \\
{\left[\mathrm{CuC}_{18} \mathrm{H}_{27} \mathrm{~N}_{3} \mathrm{O}_{11}\right] \mathrm{Cl}}\end{array}$ & $\begin{array}{l}2 \cdot 05 \\
(301)\end{array}$ & $\begin{array}{l}13,271(753 \cdot 5 \mathrm{~nm}) ; 20,000(500 \cdot 0 \mathrm{~nm}) ; \\
38,314(261 \cdot 0 \mathrm{~nm})\end{array}$ \\
\hline $\begin{array}{l}{\left[\mathrm{Cu}(\mathrm{urd})(\mathrm{L}-\mathrm{Trp})\left(\mathrm{H}_{2} \mathrm{O}\right)_{2} \mathrm{Cl}\right], \mathbf{3}} \\
{\left[\mathrm{CuC}_{20} \mathrm{H}_{27} \mathrm{~N}_{4} \mathrm{O}_{10} \mathrm{Cl}\right]}\end{array}$ & $\begin{array}{c}3 \cdot 43 \\
(301)\end{array}$ & $\begin{array}{l}16,666(600 \cdot 0 \mathrm{~nm}) ; 26,455(378 \cdot 0 \mathrm{~nm}) ; \\
38,008(263 \cdot 1 \mathrm{~nm})\end{array}$ \\
\hline $\begin{array}{l}{\left[\mathrm{Ni}(\text { urd })(\mathrm{L}-\mathrm{Ala})\left(\mathrm{H}_{2} \mathrm{O}\right)_{3}\right] \mathrm{Cl}, 4} \\
{\left[\mathrm{NiC}_{12} \mathrm{H}_{24} \mathrm{~N}_{3} \mathrm{O}_{11}\right] \mathrm{Cl}}\end{array}$ & $\begin{array}{c}2 \cdot 69 \\
(301)\end{array}$ & $\begin{array}{l}12,896(775 \cdot 4 \mathrm{~nm}) ; 14,619(684 \cdot 0 \mathrm{~nm}) \\
23,255(430 \cdot 0 \mathrm{~nm}) ; 39,339(254 \cdot 2 \mathrm{~nm})\end{array}$ \\
\hline $\begin{array}{l}{\left[\mathrm{Ni}(\text { urd })(\mathrm{L}-\mathrm{Phe})\left(\mathrm{H}_{2} \mathrm{O}\right)_{3}\right] \mathrm{Cl}, \mathbf{5}} \\
{\left[\mathrm{NiC}_{18} \mathrm{H}_{28} \mathrm{~N}_{3} \mathrm{O}_{11}\right] \mathrm{Cl}}\end{array}$ & $\begin{array}{c}3 \cdot 11 \\
(301)\end{array}$ & $\begin{array}{l}13,051(766 \cdot 2 \mathrm{~nm}) ; 14,465(691 \cdot 3 \mathrm{~nm}) ; \\
23,809(420 \cdot 0 \mathrm{~nm}) ; 38,167(262 \cdot 0 \mathrm{~nm})\end{array}$ \\
\hline $\begin{array}{l}{\left[\mathrm{Ni}(\text { urd })(\mathrm{L}-\mathrm{Trp})\left(\mathrm{H}_{2} \mathrm{O}\right)_{3}\right] \mathrm{Cl}, \mathbf{6}} \\
{\left[\mathrm{NiC}_{20} \mathrm{H}_{29} \mathrm{~N}_{4} \mathrm{O}_{11}\right] \mathrm{Cl}}\end{array}$ & $\begin{array}{l}2 \cdot 61 \\
(301)\end{array}$ & $\begin{array}{l}13,368(748 \cdot 0 \mathrm{~nm}) ; 14,836(674 \cdot 0 \mathrm{~nm}) ; \\
25,641(390 \cdot 0 \mathrm{~nm}) ; 37,593(266 \cdot 0 \mathrm{~nm})\end{array}$ \\
\hline $\begin{array}{l}{\left[\mathrm{Co}(\text { urd })(\mathrm{L}-\mathrm{Ala})\left(\mathrm{H}_{2} \mathrm{O}\right)_{3}\right] \mathrm{Cl}, 7} \\
{\left[\mathrm{CoC}_{12} \mathrm{H}_{24} \mathrm{~N}_{3} \mathrm{O}_{11}\right] \mathrm{Cl}}\end{array}$ & $\begin{array}{l}4 \cdot 08 \\
(301)\end{array}$ & $\begin{array}{l}11,098(901 \cdot 0 \mathrm{~nm}) ; 14,760(677 \cdot 4 \mathrm{~nm}) ; \\
16,276(614.4 \mathrm{~nm}) ; 38,314(261 \cdot 0 \mathrm{~nm})\end{array}$ \\
\hline $\begin{array}{l}{\left[\mathrm{Co}(\text { urd })(\mathrm{L}-\mathrm{Phe})\left(\mathrm{H}_{2} \mathrm{O}\right)_{3}\right] \mathrm{Cl}, \mathbf{8}} \\
{\left[\mathrm{CoC}_{18} \mathrm{H}_{28} \mathrm{~N}_{3} \mathrm{O}_{11}\right] \mathrm{Cl}}\end{array}$ & $\begin{array}{l}4 \cdot 09 \\
(301)\end{array}$ & $\begin{array}{l}11,187(894 \cdot 0 \mathrm{~nm}) ; 14,738(678 \cdot 5 \mathrm{~nm}) ; \\
16,273(614 \cdot 5 \mathrm{~nm}) ; 38,610(259 \cdot 0 \mathrm{~nm})\end{array}$ \\
\hline $\begin{array}{l}{\left[\mathrm{Co}(\text { urd })(\mathrm{L}-\mathrm{Trp})\left(\mathrm{H}_{2} \mathrm{O}\right)_{2} \mathrm{Cl}\right], 9} \\
{\left[\mathrm{CoC}_{20} \mathrm{H}_{27} \mathrm{~N}_{4} \mathrm{O}_{10} \mathrm{Cl}\right]}\end{array}$ & $\begin{array}{r}4 \cdot 87 \\
(301)\end{array}$ & $\begin{array}{l}11,298(885 \cdot 1 \mathrm{~nm}) ; 14,753(677 \cdot 8 \mathrm{~nm}) ; \\
16,291(613 \cdot 8 \mathrm{~nm}) ; 37,453(267 \cdot 0 \mathrm{~nm})\end{array}$ \\
\hline
\end{tabular}


Thus, it may be concluded that aminoacids act as monobasic bidentates in these complexes coordinating through amino nitrogen and carboxylate oxygen ${ }^{14-16,24-28}$. The spectra further show broad strong bands in the region $3400-3100 \mathrm{~cm}^{-1}$, which are attributed to the coordination of water molecules. These broad bands show distinct structures, which correspond to aminoacids as discussed earlier. The presence of coordinated water is further confirmed by non-ligand bands observed in the range 931$814 \mathrm{~cm}^{-1}$ due to the rocking mode of coordinated water molecules. Other low intensity bands observed in far-IR region (figure 1) in the range $565-290 \mathrm{~cm}^{-1}$ are due to $v(\mathrm{M}-\mathrm{Cl})$, $v(\mathrm{M}-\mathrm{O})$ and $v(\mathrm{M}-\mathrm{N})$ stretch $^{13,17}$. The metal-oxygen stretching frequencies could not be assigned unambiguously due to the presence of three types of $\mathrm{v}(\mathrm{M}-\mathrm{O})$ vibrations i.e., $\mathrm{M}-$ $\mathrm{COO}^{-}, \mathrm{M}-\mathrm{H}_{2} \mathrm{O}$ and $\mathrm{M}-\mathrm{C}_{4}=\mathrm{O}$. However, the data are retained in table 2 for clarity. In complexes $2,4,5,6,7$ and 8 no evidence was found for the coordination of the chloride ion.

The magnetic data pertaining to these systems are given in table 3 . The magnetic moments $2 \cdot 01,2.05$ and $2.43 \mathrm{BM}$ of $\mathrm{Cu}(\mathrm{II})$ complexes 1,2 and 3 are indicative of one unpaired electron each in these systems ${ }^{28,29}$. The magnetic data of $\mathrm{Ni}$ (II) complexes 4,5 and 6 show magnetic moments of $2.63,3.11$ and $2.61 \mathrm{BM}$, which are close to that of an octahectral $d^{8}$ system with two unpaired electrons ${ }^{28,29}$. The magnetic susceptibilities of Co(II) complexes 7, 8 and 9 show magnetic moment values of 4.08, 4.09 and 4.37 BM, and suggest high spin octahedral geometry with three unpaired electrons in these complexes ${ }^{28,29}$.

The electronic spectral data of various complexes are presented in table 3 . The electronic spectra of uridine show an absorption band at $254.2 \mathrm{~nm}$ in DMSO. This is assigned to the $\pi-\pi^{*}$ transition of the free ligand. The electronic spectra of complexes 1 , 2 and 3 show multiple bands, which are assigned to ${ }^{2} E g \rightarrow{ }^{2} T_{2 g}$ and CT transition characteristics of the $d^{9}$ system. Hence, a distorted octahedral geometry was proposed for the copper complexes ${ }^{29-31}$. The electronic spectra of the complexes 4,5 and 6 show multiple bands which are assigned to ${ }^{3} A_{2 g} \rightarrow{ }^{3} T_{2 g},{ }^{3} A_{2 g} \rightarrow{ }^{3} T_{1 g}(F),{ }^{3} A_{2 g} \rightarrow{ }^{3} T_{1 g}(P)$ and CT transitions of $d^{8}$ system. Hence, octahedral geometry was proposed for all the nickel

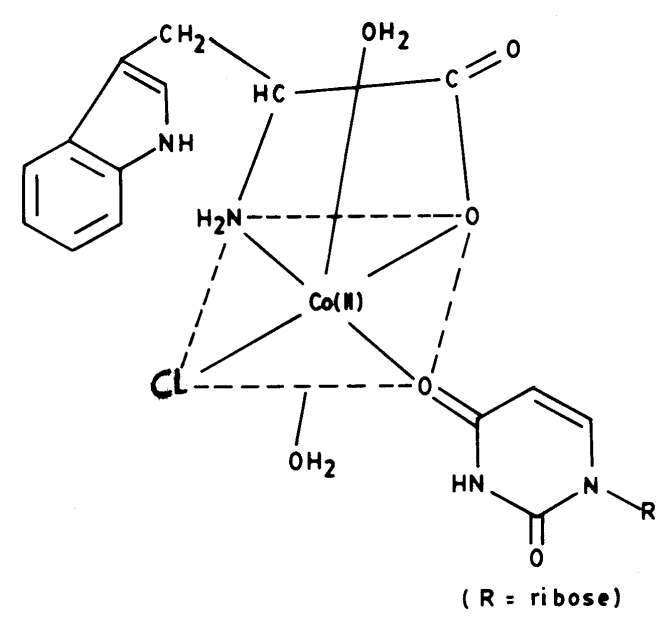

Figure 2. Structure of [Co(urd)(L-Trp) $\left.\left(\mathrm{H}_{2} \mathrm{O}\right)_{2} \mathrm{Cl}\right]$. 
complexes ${ }^{29-31}$. The electronic spectra of complexes 7, 8 and 9 show multiple bands which are assigned to ${ }^{4} T_{1 g} \rightarrow{ }^{4} T_{2 g}(F),{ }^{4} T_{1 g} \rightarrow{ }^{4} T_{1 g}(P),{ }^{4} T_{1 g} \rightarrow{ }^{4} A_{2 g}$ and CT transitions of the $d^{7}$ system. Therefore, octahedral geometry (figure 2 ) was proposed for cobalt complexes ${ }^{29,31}$.

\section{Acknowledgement}

Financial support from the University Grants Commission, New Delhi to Prof P Rabindra Reddy is gratefully acknowledged.

\section{References}

1. Garoufis A, Hatiris J and Hadjiliadis N 1990 J. Inorg. Biochem. 41195

2. Pesch F J, Prent H and Lippert B 1990 Inorg. Chim. Acta 169195

3. Rabindra Reddy P and Sudhakar K 1990 Indian J. Chem. A29 1182

4. Rabindra Reddy P and Raviprakash Reddy M 1991 Indian J. Chem. A30 1182

5. Sigel H, Fisher B E and Farkas S 1983 Inorg. Chem. 22925

6. Sabat M, Satyashur K A and Sundaralingam M 1983 J. Am. Chem. Soc. 105976

7. Marzilli L G, Castro B D, Caradonna J P, Stewar R C and Van Vurren C P 1980 J. Am. Chem. Soc. 102916

8. Chen L and Carven B M 1995 Acta Cryst. B51 1081

9. Pullman B and Pullman A 1963 Quantum biochemistry (New York: Interscience)

10. Rabindra Reddy P and Mohan Reddy A 1996 Indian J. Chem. A35 1097

11. Rabindra Reddy P and Mohan Reddy A 1998 Proc. Indian Acad. Sci. (Chem. Sci.) 110385

12. Geary W J 1971 Coord. Chem. Rev. 781

13. Bellamy L J 1975 The infrared spectra of complex molecules 3rd edn (London: Chapman and Hall)

14. Green A C, Place H, Willett R D and Legg J I 1986 Inorg. Chem. 254672

15. Kasselouri S, Garoufis A and Hadjiliadis N 1987 Inorg. Chim. Acta 13523

16. Ilavarasi R, Rao M S N and Udupa M R 1997 Proc. Indian Acad. Sci. (Chem. Sci.) 10979

17. Nakamoto K 1970 Infrared spectra of inorganic and coordination compounds (New York: Wiley Interscience)

18. Deshpande S V, Sharma R K and Srivastava T S 1983 Inorg. Chim. Acta 7813

19. Fiol J J, Terron A and Moreno V 1986 Inorg. Chim. Acta 125159

20. Fiol J J, Terron A, Mulet D and Moreno V 1987 Inorg. Chim. Acta 135197

21. Goodgame M and Johns K W 1977 J. Chem. Soc., Dalton Trans. 1294

22. Uemura T, Shimura T, Nakamishi H, Tomahiro T, Nagawa Y and Okuno (Yohmei) H 1991 Inorg. Chim. Acta 18111

23. Iakovidis A, Hadjiliadis N, Schollhorn H, Thewalt U and Trotscher G 1989 Inorg. Chim. Acta 164221

24. Kasselouri S and Hadjiliadis N 1990 Inorg. Chim. Acta 16815

25. Laurie S H 1967 Aust. J. Chem. 202597

26. Lippert B, Thewalt U, Schollhorn H, Goodgame D M L and Rollins R W 1984 Inorg. Chem. 232807

27. Manjula V and Bhattacharya P K 1996 Proc. Indian Acad. Sci. (Chem. Sci.) 108431

28. Figgis B N and Lewis J 1964 Progress in inorganic chemistry (ed.) F A Cotton (New York: Interscience)

29. Lewis J and Wilkins R G 1967 Modern coordination chemistry (New York: Interscience)

30. Casella L and Gullotti M 1981 J. Am. Chem. Soc. 1036338

31. Lever A B P 1968 Inorganic electronic spectroscopy (Amsterdam: Elsevier) 